\title{
Penyuluhan Pendidikan Penyadaran Lingkungan untuk Mendukung Pelaksanaan Program Adiwiyata di SDN Inpres Kampus Tamalanrea Kota Makassar
}

\author{
Achmad Zubair ${ }^{1 *}$, Roslinda \\ Ibrahim, Asiyanti T. Lando, Irwan Ridwan, Kartika Sari, Nurjannah Oktorina \\ Departemen Teknik Lingkungan, Universitas Hasanuddin ${ }^{1 *}$ \\ achmad.zubair@gmail.com ${ }^{1 *}$
}

\begin{abstract}
Abstrak
Seiring dengan permasalahan lingkungan hidup yang sering terjadi disekitar kita, melalui pendidikan diharapkan mampu menanamkan kepedulian para generasi muda untuk menjaga lingkungan, karena generasi muda adalah pewaris penghuni bumi di masa yang akan datang. Undang-undang Nomor 32 Tahun 2009 Pasal 65 poin keempat tentang Perlindungan dan Pengelolaan Lingkungan Hidup, menyebutkan bahwa setiap orang berhak dan berperan dalam pengelolaan lingkungan hidup. Hal ini berarti setiap individu harus memiliki rasa tanggung jawab terhadap lingkungan dan sikap peduli untuk menjaga lingkungan. Tujuan kegiatan ini adalah untuk meningkatkan pengetahuan dan wawasan siswa-siswi mengenai pendidikan penyadaran lingkungan untuk mendukung pelaksanaan program adiwiyata. Tingkat kepedulian dan peran serta warga sekolah dalam bidang pelestarian lingkungan sudah cukup tinggi, tetapi tingkat kepedulian tersebut masih perlu ditingkatkan sehingga dapat mempengaruhi pengetahuan dan perilaku secara terus menerus serta mendorong aktivitas atau tindakan nyata secara meluas dalam usaha perbaikan SD Negeri Inpres Kampus Unhas. Metode yang digunakan untuk mencapai tujuan dan target yang telah ditetapkan adalah dengan cara melaksanakan pelatihan dan penyuluhan yang diharapkan berguna bagi siswa dan guru. Dengan terlaksananya kegiatan pengabdian ini, pengetahuan siswa dan guru mengenai pendidikan penyadaran lingkungan untuk mendukung pelaksanaan program adiwiyata meningkat. Pengetahuan dan keterampilan yang telah dimiliki diharapkan dapat ditularkan dan menjadi contoh bagi sekolah dasar disekitar Kota Makassar.
\end{abstract}

Kata Kunci: Penyuluhan; pelatihan; kompos; SDN Inpres; adiwiyata

\begin{abstract}
The environmental problems that often occur around us, through education is expected to be able to instill the care of the younger generation to protect the environment, because the younger generation is the heir to the inhabitants of the earth in the future. Base on the Indonesian regulation, number 32 (2009) said that everyone has the right and role in environmental management. This means that every individual must have a sense of responsibility towards the environment and a caring attitude to protect the environment. The purpose of this activity is to increase the knowledge and insight of students regarding environmental awareness education to support the implementation of the adiwiyata program. The level of concern and participation of school members in the field of environmental preservation is already quite high, but the level of concern still needs to be improved so that it can influence knowledge and behavior continuously and encourage widespread activities or concrete actions in efforts to improve the Unhas State Inpres SD State Elementary School. The method used to achieve the stated goals and targets is to carry out training and counseling that are expected to be useful for students and teachers. With the implementation of this community service activity, the knowledge of students and teachers about environmental awareness education to support the implementation of the adiwiyata program increases. Knowledge and skills possessed are expected to be transmitted and become an example for elementary schools around Makassar City.
\end{abstract}

Keywords: Counseling; training; composting; elementary school; adiwiyata 


\section{Pendahuluan}

Sekolah adalah suatu lembaga yang dirancang sebagai tempat manusia untuk memperoleh pendidikan dengan bimbingan para guru. Seiring dengan permasalahan lingkungan hidup yang sering terjadi disekitar kita, melalui pendidikan diharapkan mampu menanamkan kepedulian para generasi muda untuk menjaga lingkungan, karena generasi muda adalah pewaris penghuni bumi di masa yang akan datang. Undang-undang Nomor 32 Tahun 2009 Pasal 65 poin keempat tentang Perlindungan dan Pengelolaan Lingkungan Hidup, menyebutkan bahwa setiap orang berhak dan berperan dalam pengelolaan lingkungan hidup. Hal ini berarti setiap individu harus memiliki rasa tanggung jawab terhadap lingkungan dan sikap peduli untuk menjaga lingkungan..

Sekolah berkewajiban untuk membangkitkan kepekaan dan kesadaran akan lingkungan pada generasi muda, membuka wawasan dan mendidik siswa untuk berinteraksi dan bersikap dengan penuh tanggung jawab khususnya terhadap lingkungan. Lingkungan sekolah merupakan wadah belajar dan pembentukan karakter dan perilaku anak untuk mengembangkan berbagai aspek menyangkut pengembangan sikap, pengetahuan maupun keterampilan. Untuk itu dalam rangka upaya mendukung perlindungan dan pengelolaan lingkungan hidup sekaligus meningkatkan pengetahuan masyarakat mengenai lingkungan, serta untuk merubah perilaku manusia yang tidak ramah lingkungan, dibutuhkan pengenalan akan lingkungan hidup melalui jalur pendidikan sejak dini. Pendidikan lingkungan hidup secara formal dapat mempengaruhi aspek kognitif, aspek afektif dan aspek psikomotorik. Pendidikan anak sejak usia dini merupakan hal yang penting bagi pertumbuhan mental dan kepribadian anak. Dengan tumbuhnya pemahaman, khususnya bagi peserta didik, diharapkan akan muncul rasa peduli terhadap lingkungan yang diwujudkan dalam bentuk sikap dan perilaku yang berorientasi pada pengembangan etika bagi individu dan kelompok sosial).

Menjalankan pola lingkungan yang sehat dan bersih serta mengupayakan perlindungan dan pengelolaan lingkungan hidup di sekolah tidaklah mudah. Pada kenyataannya masih banyak warga sekolah yang tidak peduli terhadap lingkungan hidup. Tidak jarang warga sekolah terutama siswa masih melanggar peraturan tentang kebersihan lingkungan, misalnya dengan membuang sampah sembarangan meskipun telah disediakan tempat sampah dengan jumlah yang memadai di sekolah, mencoret-coret meja dan dinding di lingkungan sekolah, bahkan memetik atau mematahkan tumbuhan yang ada. Untuk itu dibutuhkan adanya pendidikan lingkungan hidup pada kurikulum sekolah.

Secara formal pendidikan lingkungan hidup menjadi salah satu alternatif yang rasional untuk memasukkan pendidikan lingkungan ke dalam kurikulum. Pendidikan lingkungan hidup merupakan salah satu faktor penting dalam keberhasilan dalam pengelolaan lingkungan hidup dan juga menjadi sarana yang sangat penting dalam menghasilkan sumber daya manusia yang dapat melaksanakan prinsip pembangunan berkelanjutan.

Pendidikan lingkungan hidup (PLH) merupakan salah satu faktor penting untuk meminimalisasi kerusakan lingkungan hidup dan merupakan sarana penting dalam menghasilkan sumberdaya manusia yang dapat melaksanakan prinsip pembangunan berkelanjutan serta memiliki karakter cinta lingkungan sejak dini (Landriany 2014), sebagai upaya untuk meningkatkan pemahaman dan kepedulian masyarakat dalam mencari solusi dan mencegah timbulnya masalah lingkungan di masa yang akan datang. Hal ini sejalan dengan temuan Benedict yang menyatakan bahwa 
pembelajaran lingkungan secara aktif merupakan kunci untuk mencapai etika dan perilaku lingkungan (Uzun dan Keles, 2012).

Kementerian Lingkungan Hidup dan Kehutanan melaksanakan program pemberdayaan masyarakat pada komunitas pendidikan yang kemudian dikenal dengan Program Adiwiyata, sebagai tindak lanjut kesepakatan bersama Kementerian Pendidikan Nasional. Program Adiwiyata dilaksanakan secara menyeluruh pada tiap provinsi di Indonesia sejak tahun 2007 (KLH 2010), dan merupakan strategi percepatan pelaksanaan pendidikan lingkungan hidup pada jalur formal, namun bersifat voluntary. Ruang lingkup program Adiwiyata melingkupi pembinaan, penilaian, dan pemberian penghargaan. Menurut data yang tercatat di Kementerian Lingkungan Hidup dan Kehutanan hingga tahun 2014 jumlah peserta program sekolah Adiwiyata adalah sebanyak 5.593 sekolah, dimana sebanyak 2.693 sekolah telah menerima penghargaan Adiwiyata.

Salah satu program pendidikan yang mengarah pada usaha menanamkan sikap peduli lingkungan pada siswa yaitu Program Adiwiyata. Program Adiwiyata berperan dalam menciptakan situasi dan kondisi yang mendukung perkembangan karakter peduli lingkungan (Darning et al., 2016). Program Adiwiyata telah disepakati pada tanggal 3 Juni 2005 oleh Menteri Negara Lingkungan Hidup dengan Menteri Pendidikan Nasional. Realisasi dari kesepakatan tersebut, pada tanggal 21 Februari 2006 telah dicanangkan Program Adiwiyata, yaitu sekolah peduli dan berbudaya lingkungan. Program Adiwiyata dicanangkan untuk mendorong dan membentuk sekolah-sekolah di Indonesia agar dapat turut melaksanakan upaya-upaya pemerintah menuju pelestarian lingkungan dan pembangunan berkelanjutan bagi kepentingan generasi sekarang maupun yang akan datang.

Penghargaan Adiwiyata ditujukan untuk sekolah-sekolah yang telah berhasil membentuk generasi peduli lingkungan. Program ini diarahkan kepada sekolah setingkat SD/MI, SMP/MTS, SMA/MA, dan SMK/MAK dengan target sasaran 10 persen dari total sekolah di Indonesia atau kira-kira sebanyak 25.825 sekolah. Program Adiwiyata dilakukan secara berjenjang dari tingkat Kabupaten/Kota, tingkat Provinsi, tingkat Nasional, serta tingkat Adiwiyata Mandiri. Sekolah yang telah mencapai kriteria Kabupaten/Kota dapat diusulkan ke Provinsi oleh Pemerintah Daerah, dan seterusnya diusulkan ke tingkat Nasional.

Program Adiwiyata bertujuan untuk menciptakan kondisi yang baik bagi sekolah untuk menjadi tempat pembelajaran dan penyadaran warga sekolah (guru, murid dan pekerja lainnya), yang diwujudkan dalam bentuk: (1) Pengembangan kebijakan sekolah peduli dan berbudaya lingkungan, (2) Pengembangan kurikulum berbasis lingkungan, (3) Pengembangan kegiatan lingkungan berbasis partisipatif, dan (4) Pengembangan dan pengelolaan sarana pendukung sekolah berbudaya lingkungan seperti: hemat energi atau penggunaan energi alternatif, penghematan air, pengelolaan sampah, penggunaan pupuk organik. Diharapkan melalui program ini dikemudian hari warga sekolah tersebut dapat turut bertanggung jawab dalam upayaupaya penyelamatan lingkungan dan pembangunan berkelanjutan (KLH buku panduan adiwiyata, 2012).

SD Negeri Inpres Kampus Unhas merupakan salah satu sekolah di Kota Makassar yang merintis green school dalam kegiatan akademik. program Sekolah Adiwiyata ini harus terus didukung oleh seluruh warga sekolah, terutama siswa sebagai agent of change atau agen pembawa perubahan untuk menciptakan lingkungan yang lebih baik dari sebelumnya. Tingkat kepedulian dan peran serta warga sekolah dalam bidang pelestarian lingkungan sudah cukup tinggi, tetapi 
tingkat kepedulian tersebut masih perlu ditingkatkan sehingga dapat mempengaruhi pengetahuan dan perilaku secara terus menerus serta mendorong aktivitas atau tindakan nyata secara meluas dalam usaha perbaikan SD Negeri Inpres Kampus Unhas.

Dengan adanya penyuluhan pendidikan penyadaran lingkungan untuk mendukung pelaksanaan program adiwiyata di SD Negeri Inpres Kampus Unhas maka diharapkan prilaku peduli lingkungan yang ada di sekolah, hidup bersih dan sehat dapat ditingkatkan karena keterlibatan pada program tersebut merupakan salah satu upaya pelaksanaan program Sekolah Adiwiyata.

\section{Metode Untuk Menangani Permasalahan}

Kegiatan Pengabdian masyarakat dilaksanakan melalui dua tahapan yaitu tahap persiapan dan tahap pelaksanaan kegiatan. Prosedur persiapan dan pelaksanaan kegiatan untuk mewujudkan solusi yang ditawarkan dilaksanakan secara bersama anggota tim pengusul dengan mitra.

1) Tahap persiapan meliputi kegiatan: a)pembentukan tim yang dilanjutkan dengan rapat untuk menentukan tema, lokasi dan mitra kerjasama, b)koordinasi dengan pihak mitra untuk mendiskusikan permasalahan yang utama yang dihadapi masyarakat dan solusi yang ditawarkan untuk menyelesaikan permasalahan tersebut serta memilih pendekatan untuk merealisasikan solusi yang telah disepakati, dan c)survey pendahuluan ke lokasi yang menjadi target pelaksanaan kegiatan dan rapat persiapan tim untuk membuat usulan pengabdian masyarakat.

2) Tahap Pelaksanaan meliputi kegiatan: a)penyampaian undangan dan persiapan tempat pelaksanaan kegiatan berserta penyediaan alat dan bahan yang akan digunakan, b)kegiatan penyuluhan untuk menjelaskan materi mengenai penyuluhan cuci tangan pakai sabun, teknologi biogas dan kompos, jenis-jenis sampah, dan c)kegiatan pelatihan pembuatan kompos dari sampah organik.

Keberhasilan pelaksanaan kegiatan sangat ditentukan oleh kerjasama antara anggota tim pengusul dengan mitra. Partisipasi mitra diwujudkan dalam penyampaian informasi mengenai permasalahan yang dihadapi oleh masyarakat setempat dan menjadi fasilitator yang menghubungkan antara tim pengusul pengabdian masyarakat dari Universitas Hasanuddin dengan masyarakat.

Keberlanjutan program sangat diharapkan guna terciptanya kehidupan yang sehat dan lebih berkualitas. Besar harapan keberlanjutan program ini lebih meluas lagi sampai pada sekolah dasar se-Kota Makassar. Pembuatan kompos ini dapat ditularkan atau menjadi contoh bagi sekolah dasar di sekitar Kota Makassar.

\section{Hasil dan Diskusi}

Kegiatan pengabdian ini dilaksanakan di SDN Inpres Kampus Unhas Kota Makassar selama 1 hari yang dihadiri sekitar 50 orang siswa dan guru. Kegiatan yang dilakukan adalah penyuluhan cuci tangan pakai sabun, teknologi biogas dan kompos, pembuatan kompos, dan klasifikasi sampah sekolah.

Kegiatan penyuluhan dilaksanakan dengan tujuan untuk meningkatkan pengetahuan dan pemahaman siswa-siswi dan guru mengenai cuci tangan pakai sabun, teknologi biogas dan kompos, pembuatan kompos, dan klasifikasi sampah sekolah. Dengan mengikuti kegiatan penyuluhan, diharapkan siswa-siswi dan guru memahami pentingnya hidup bersih sehingga 
dapat meningkatkan kualitas hidupnya. Kegiatan penyuluhan diawali dengan sambutan oleh Ketua Tim Pengabdian Kepada Masyarakat dari Departemen Teknik Lingkungan, Unhas Dr. Ir. Achmad Zubair kemudian dilanjutkan dengan penyajian materi oleh tim pengabdian. Rangkaian akhir dari kegiatan penyuluhan adalah diskusi atau tanya jawab.

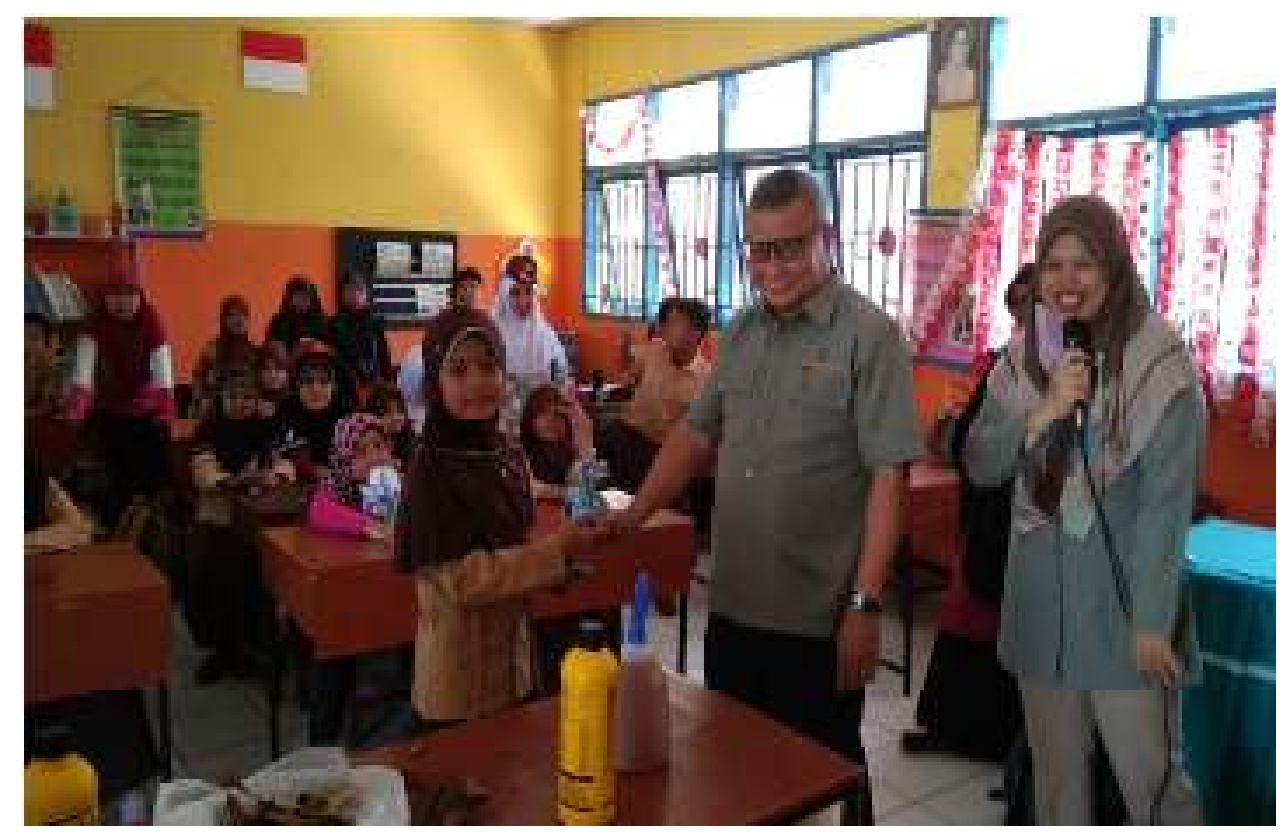

Gambar 1. Sambutan Ketua Tim PKM dari Dept. Teknik Lingkungan Unhas

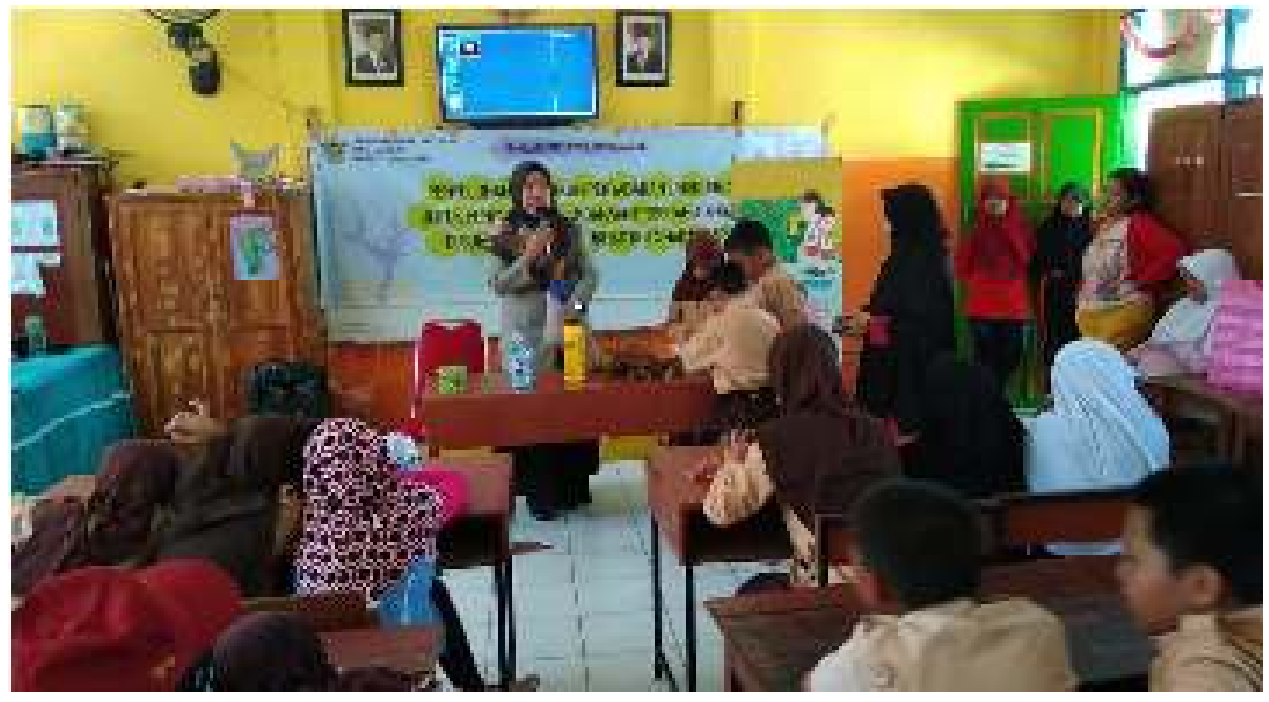

Gambar 2. Pemaparan Materi oleh Tim PKM 


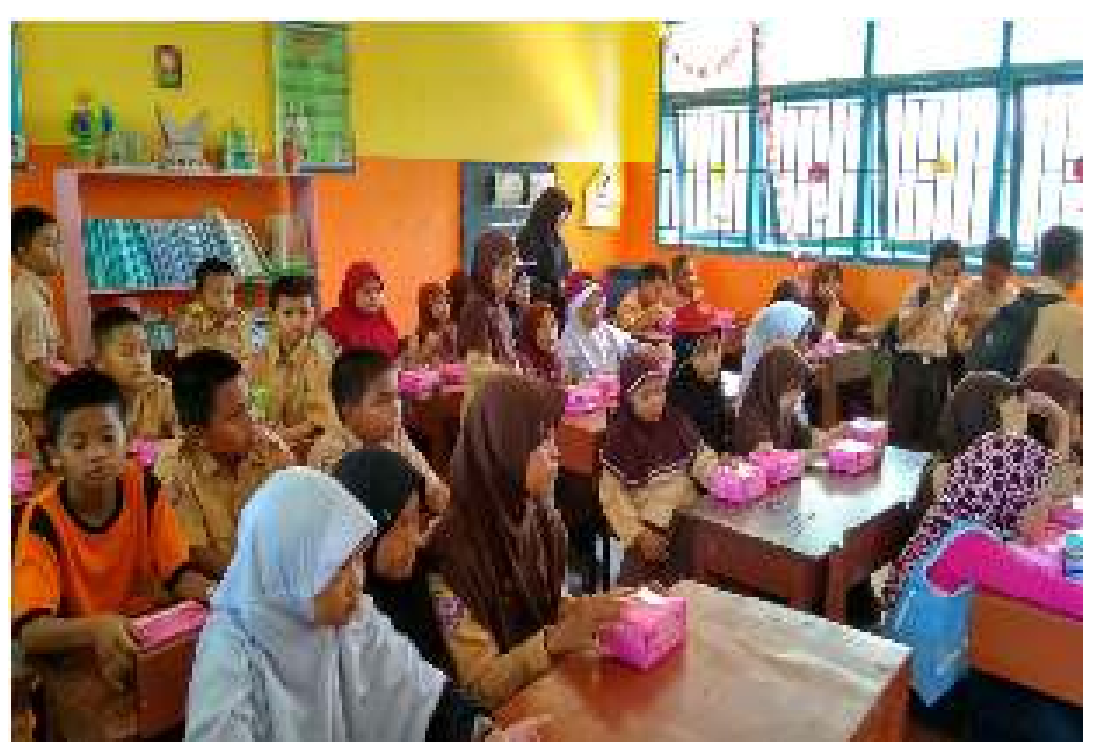

Gambar 3. Peserta Kegiatan PKM

Kegiatan penyuluhan bertujuan untuk meningkatkan pengetahuan dan keterampilan siswa-siswi dan guru dalam mengurangi timbulan sampah di sekolah. Pengenalan teknologi pengolahan sampah organik dengan metode komposting melalui penyuluhan dapat menjadi acuan bagi siswa dan guru untuk mengurangi timbulan sampah organik di sekolah. Pada kesempatan tersebut dilakukan pembuatan kompos dengan menambahkan EM-4 sebagai bioaktivator.

Strategi mengubah masalah sampah menjadi produk bermanfaat salah satunya adalah dengan mengubah sampah organik menjadi pupuk kompos menggunakan metode Takakura. Kompos takakura dibuat dengan cara Takakura Home Method Composting, sebuah metode pembuatan kompos yang ditujukan untuk mendaur-ulang sampah dapur.

Kompos atau Pupuk Kompos adalah salah satu pupuk organik buatan manusia yang dibuat dari proses pembusukan sisa-sisa bahan organik (tanaman maupun hewan). Proses pengomposan dapat berlangsung secara aerobik dan anaerobik yang saling menunjang pada kondisi lingkungan tertentu. Proses ini disebut juga dekomposisi atau penguraian. Kompos memiliki banyak manfaat yang ditinjau dari beberapa aspek.

\section{1) Aspek Ekonomi:}

- Menghemat biaya untuk transportasi dan penimbunan limbah

- Mengurangi volume/ukuran limbah

- Memiliki nilai jual yang lebih tinggi dari pada bahan asalnya

2) Aspek Lingkungan:

- Mengurangi polusi udara karena pembakaran limbah dan pelepasan gas metana dari sampah organik yang membusuk akibat bakteri metanogen di tempat pembuangan sampah

- Mengurangi kebutuhan lahan untuk penimbunan

- Mengurangi kerusakan lingkungan akibat penggunaan pupuk kimia yang selama ini banyak digunakan petani

3) Aspek bagi tanah/tanaman:

- Meningkatkan kesuburan tanah

- Memperbaiki struktur dan karakteristik tanah 
- Meningkatkan kapasitas penyerapan air oleh tanah

- Meningkatkan aktivitas mikroba tanah

\subsection{Persiapan Media Pengomposan}

- Siapkan keranjang plastik Untuk membuat kompos ukuran panjang $45 \mathrm{~cm}$, lebar $33 \mathrm{~cm}$ dan tinggi $43 \mathrm{~cm}$, kardus bekas untuk melapisi sisi-sisi dalam keranjang, siapkan sekam padi dalam wadah plastik, tebal sekam 10-15 cm dari dasar keranjang, dan masukkan bantalan sekam kemudian kompos jadi (kompos siap pakai) ke dalam keranjang Takakura setebal 15-20 cm dari bantalan sekam. Selanjutnya, komposter Takakura siap dipakai. lalu ambil mikroorganisme cair, tuangkan ke dalam sprayer.

- Semprotkan mikroorganisme cair dengan menggunakan sprayer secara merata dengan sesekali mengaduk sekam dengan tangan

- Gunting jaring untuk membuat dua kantong sesuai ukuran alas dan bagian atas keranjang dengan cara menjahit bagian tepi jaring.

- Setelah jaring berbentuk kantong, isi masing-masing kantong jaring dengan sekam secukupnya lalu jahit hingga menyerupai bantal

- Ambil kardus dan potong dengan menggunakan gunting sesuai ukuran sekeliling keranjang lalu tempelkam potongan kardus tadi di sekeliling bagian dalam keranjang

- Setelah bagian dalam keranjang terlapisi kardus, letakkan bantal sekam pada alas keranjang

- Semprot Microorganisme cair pada permukaan luar dalam kardus dan bantal sekam dengan menggunakan sprayer hingga basah merata (EM4/ Efektive Mikroorganisme)

- Siapkan bak lalu isi dengan kompos dan pupuk ampas tebu lalu aduk hingga merata.

- Masukkan campuran kompos dan pupuk ampas tebu ke dalam keranjang yang sudah terlapisi kardus

- Sisa-sisa makanan dan sayuran dipotong kecil-kecil semakin kecil materi semakin cepat penguraiannya. Gali starter kompos di dalam keranjang tersebut dengan cetok. Luasan dan kedalaman galian sesuaikan dengan banyaknya sampah yang hendak dimasukkan.

- Masukkan sampah organik segar yang sebelumnya telah dicacah terlebih dahulu, pada lubang yang digali. Kemudian diaduk dan dicampur dengan kompos yang sudah jadi, tusuk-tusuk sampah tersebut dengan cetok. hingga sampah berada di tengah-tengah campuran pupuk kompos dan pupuk ampas tebu; usahakan semua sampah tertibun media

- Timbun sampah tadi dengan kompos di tepian lubang. Tutup kompos tersebut dengan bantalan sekam yang sudah disemprot dengan Mikroorganisme cair. Tutup permukaan keranjang dengan kain. Masukkan termometer sebagai alat pengukur suhu pada saat proses pengomposan

- Tutup bagian mulut keranjang dengan menggunakan kain stocking agar serangga kecil tidak masuk.

Untuk mempercepat proses pengomposan, media dalam komposter Takakura tidak boleh terlalu kering, untuk itu apabila dirasa kering ditambahkan air atau larutan EM4 secukupnya, percikan air bersih sambil diaduk rata, namun jangan terlalu basah. Selanjutnya tutup kembali keranjang dengan bantal sekam dan tutup keranjang. Pembuatan kompos dengan metode takakura ini memakan waktu sekitar 1 bulan, setelah dirasa jadi langsung dipisahkan antara yang sudah mengurai dengan yang masih menggumpal dengan saringan dari kawat strimin. Letakkan 
keranjang Takakura di tempat yang terhindar dari sinar matahari langsung. Suhu yang ideal pada proses Pengomposan adalah $60^{\circ} \mathrm{C}$.

\subsection{Cara Pemanenan}

Bila Kompos di dalam keranjang takakura telah penuh, ambil $1 / 3$ nya dimatangkan selama seminggu di tempat yang tidak terkena sinar matahari secara langsung. Sisanya yang $2 / 3$ bisa kita gunakan kembali sebagai starter untuk pengolahan berikutnya.

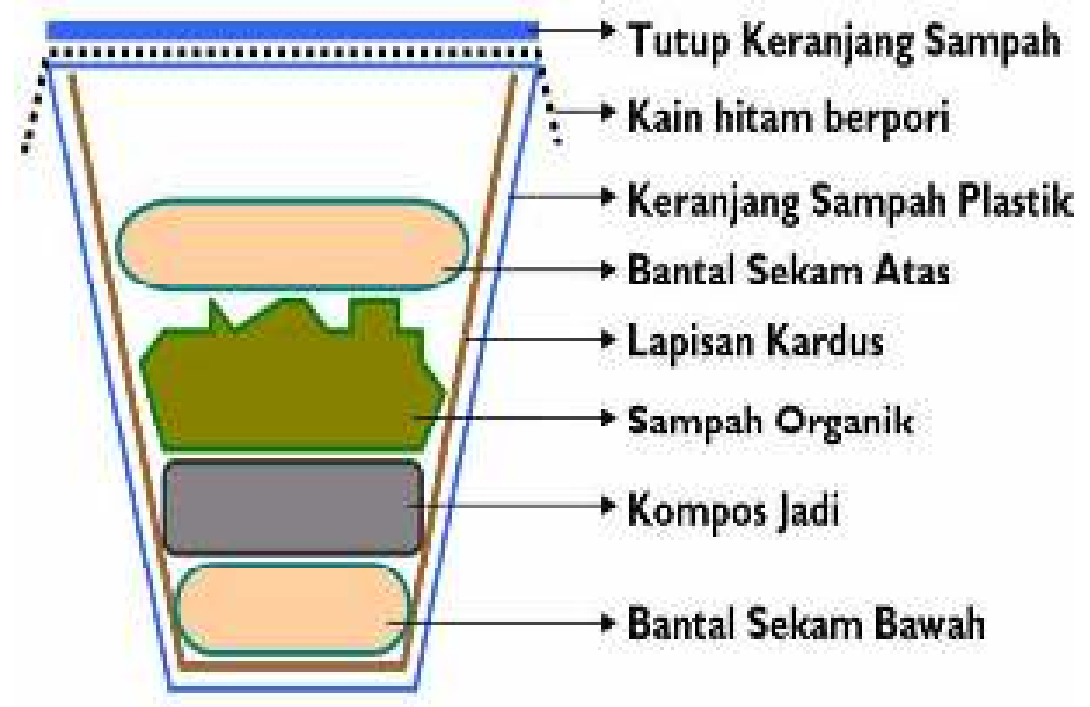

Gambar 5. Pembuatan Kompos Dari Sampah Organik

\section{Kesimpulan}

Pelaksanaan kegiatan penyuluhan dan pelatihan berkontribusi pada peningkatan pengetahuan dan pemahaman siswa dan guru mengenai pendidikan penyadaran lingkungan untuk mendukung pelaksanaan program adiwiyata di SDN Inpres Kampus Unhas Kota Makassar, klasifikasi sampah, dan teknologi composting yang dapat digunakan untuk mereduce sampah organik. Selain itu siswa dan guru juga telah memiliki keterampilan untuk membuat kompos. Dengan berbekal kemampuan pengetahuan dan keterampilan yang ditularkan oleh tim PKM unhas, diharapkan siswa dan guru dapat mengurangi timbulan sampah yang dihasilkan.

Pelaksanaan kegiatan pengabdian yang dilaksanakan di SDN Inpres Kampus Unhas dianggap tepat sasaran karena ilmu dan keterampilan yang diberikan oleh tim PKM Unhas telah membantu siswa-siswi untuk mengurangi timbulan sampah sekolah yang selama ini dihadapi.

\section{Saran}

Siswa-siswi harus memperhatikan karakter dan jenis sampah yang akan dijadikan kompos supaya kualitas kompos yang dihasilkan baik. Selain itu, masyarakat seharusnya memiliki keinginan untuk menularkan ilmu dan keterampilan yang telah diterima ke sekolah sekitar yang membutuhkan. 


\section{Ucapan Terima Kasih}

Penulis mengucapkan terima kasih kepada Dekan Fakultas Teknik Universitas Hasanuddin untuk dukungan pelaksanaan kegiatan Program Kemitraan Masyarakat (PKM) Universitas Hasanuddin.

\section{Daftar Pustaka}

Darning et al. 2016. Peran Program Adiwiyata Dalam Pengembangan Karakter Peduli Lingkungan Siswa : Studi Kasus Di SMK N 2 Semarang. Jurnal Unnes. Vol 5(1).

Kementerian Lingkungan Hidup. 2012. Panduan Adiwiyata Sekolah Peduli dan Berwawasan Lingkungan. Semarang: Pemerintah Provinsi Jawa Tengah Badan Lingkungan Hidup.

Paryadi, Sugeng. 2008. Konsep Pengelolaan Lingkungan Sekolah (Green School). Cianjur: Direktorat Jenderal PMPTK. Departemen Pendidikan Nasional.

Rahmadi, Takdir. 2011. Hukum lingkungan di Indonesia. Jakarta: Rajagrafindo Persada.

Saputro, R. 2014. Implementasi Program Adiwiyata Dalam Pengelolaan Lingkungan Sekolah di SMA Negeri 1 Jekulo Kudus. Skripsi, Universitas Negeri Semarang: Fakultas Ilmu Sosial.

Setyowati, O. 2014. Pelaksanaan Program Sekolah Adiwiyata dan Tingkat Partisipasi Siswa di SMKN 2 Semarang. Skripsi, Universitas Negeri Semarang: Fakultas Ilmu Sosial.

Sinta Selvi, 2014. Kebijakan Sekolah Dan Partisipasi Siswa Dalam Pelaksanaan Program Adiwiyata Di SMP Negeri 1 Jakenan Kabupaten Pati. Jurnal Geografi. Vol 11 (2). 